\title{
The Eleme petrochemicals company and its impact on the levels of some Physiochemical Parameters from Eleme Creeks, Port Harcourt, Rivers State, Nigeria.
}

\author{
J.D. Nwineewii ${ }^{1}$ and U.J. Ibok ${ }^{2}$ \\ ${ }^{1}$ Department of Chemistry,,Ignatius Ajuru University of Education, Rumuolumeni, Port Harcourt, Rivers State, \\ Nigeria. \\ ${ }^{2}$ Department of Pure and Applied Chemistry,University of Calabar, Calabar, Nigeria.
}

\begin{abstract}
The Eleme Petrochemicals Company is one of the largest industrial establishments in Eleme, Rivers State of Nigeria, and generates its wastes into the richEleme Creeks which are believed to have polluted the water body as claimed by the indigene. To actually verify this claim, a study was carried out to investigate the levels of some Physiochemical Parameters viz dissolved oxygen, biological oxygen demand, chemical oxygen demand, sulphate, phosphate, sodium ion, potassium ion, calcium ion, magnesium ion and oil and grease from Eleme creeks. In investigating the levels of these parameters, water sample were collected from ten different locations for a period of eight months (ieJuly2010-February 2011) and standard method as stipulated by APHA were followed. The results of the study show that the mean concentration of $\mathrm{SO}_{4}^{2-}, \mathrm{PO}_{4}{ }^{3-}, \mathrm{Na}^{+}, \mathrm{K}^{+}, \mathrm{Mg}^{2+}, \mathrm{Ca}^{2+}$, Oil and grease were within the national and international limits while those of DO, COD and BOD were not within the limits. This of course posed some possible health risks to users of the creeks. The results of the study were higher compared with that provided by the Environmental Impact Assessment study carried out by the company in 1992. Also, the mean concentrations of parameters in the dry season were generally higher compared to the rainy season. The two way ANOVA show that there was a significant difference in the mean concentration of the analysed parameters between sampling locations and sampling periods except for $\mathrm{Na}^{+}$.
\end{abstract}

Key words: Petrochemicals, Physiochemical parameters, Impact, Eleme, Upstream, Downstream, Feedstock, Assessment.

\section{Introduction}

The Eleme petrochemicals complex is an olefin-based multi-petrochemical complex with liquid natural gas as its main feed-stock, designed to produce a range of intermediate feed-stocks for various downstream process units. The olefin plant and downstream process units are for the production of butene-1, poly ethylene and poly propylene (Eleme Petrochemicals EIA, 1992). Petrochemical industries are involved in the production of several chemicals which fit into one or more of the following four categories; Basic raw materials, Key intermediates, Minor intermediates, End products. As a result of rapid industrialization arising from modern and sophisticated technology various synthetic materials has been introduced into our environment. Some of them may be toxic or carcinogenic. The wastes arising from these find their way into our water bodies, rendering them unsafe for consumption while the aquatic habitat find it difficult to breed well. From impact studies, it has been noted that it took several years to clean up top and subsoil after spill. In 1994, the oil spills at Yorla (Kpean) in Khana Local Government Area of Rivers State affected many villages where properties worth millions of naira were destroyed (Nwineewii, 2000).

In recent years in Nigeria, the remarkable population growth, urbanization, oil boom and the subsequent establishment/expansion of industries have increased the volume and strength of wastes, which now concentrate on a few nodal points. These industrial developments have brought about a significant increase in the quantity of discharges and a wide variety of pollutants reaching the air, land and water bodies. Of all natural environmental resources, water is the most severely threatened by pollution. The southern part of Nigeria is an area of active petroleum and petrochemicals exploration and exploitation thus exposing the rivers in these areas to additional risk of pollution by petroleum and petrochemicals related sources. Therefore proper pollution control measures require sound baseline information on the natural ecosystem. Such information on Nigeria Rivers and creeks is scanty and in most instances limited in scope regarding sampling strategies, thus making the results of limited practical use. Environmental chemists and other scientists now face the challenge of determining appropriate waste disposal techniques to sanitize our environment (Alo, 2003). Moreover, a look at some of our major cities would reveal the abundance of refuse and wastes that line the roads, river banks, markets and motor parks, in addition to those at the traditional refuse dumps (Ogodo, 2008). Akumagba, (2001) noted that the rate of waste generation has increased tremendously and some synthetic materials have appeared in solid waste collections. One of such synthetic materials is plastics, a product of petrochemicals origin. 
Ogodo(2001) reacted and opined that "our environment is our life". We will insist on a clean and safe environment and environmental rights.

\section{Study Location}

The Eleme creek (In Ogoniland) is 10km North East of Port Harcourt, the capital of Rivers State in the Niger Delta region of Nigeria. Port Harcourt is the main industrial city of the Niger Delta region of Nigeria. The Port Harcourt Township is located on the South East flank of Niger Delta on the edge of the dry main land which is contiguous with the site of the ElemePetrochemicals Company. TheEleme Petrochemicals Company occupies about 4, 200 hectares of land in the vicinity of the villages of Akpajo, Aleto and Agbonchia in Eleme, Eleme Local Government area of Rivers State on the Port Harcourt-Bori segment of the East-West road (Eleme Petrochemicals EIA, 1992). The Eleme Petrochemicals Company discharges its effluents into the creek which is channeled into the Okrika River which empties finally into the Bonny River (see Fig.1). Apart from the Petrochemicals Company, other activities take place within the vicinity of the creek. These include dredging, fishing, farming, cow roasting and housing estate.

For purposes of this work, the creek was divided into ten locations. The locations were location I(Agbonchia1), location2(Agbonchia2),location3(petrochemicals),location4(Dredging), location5(slaughter), location6(Railway), location7(NNPC QTRS), location8(Abam), location9(Ogan), location10(Okrika River).

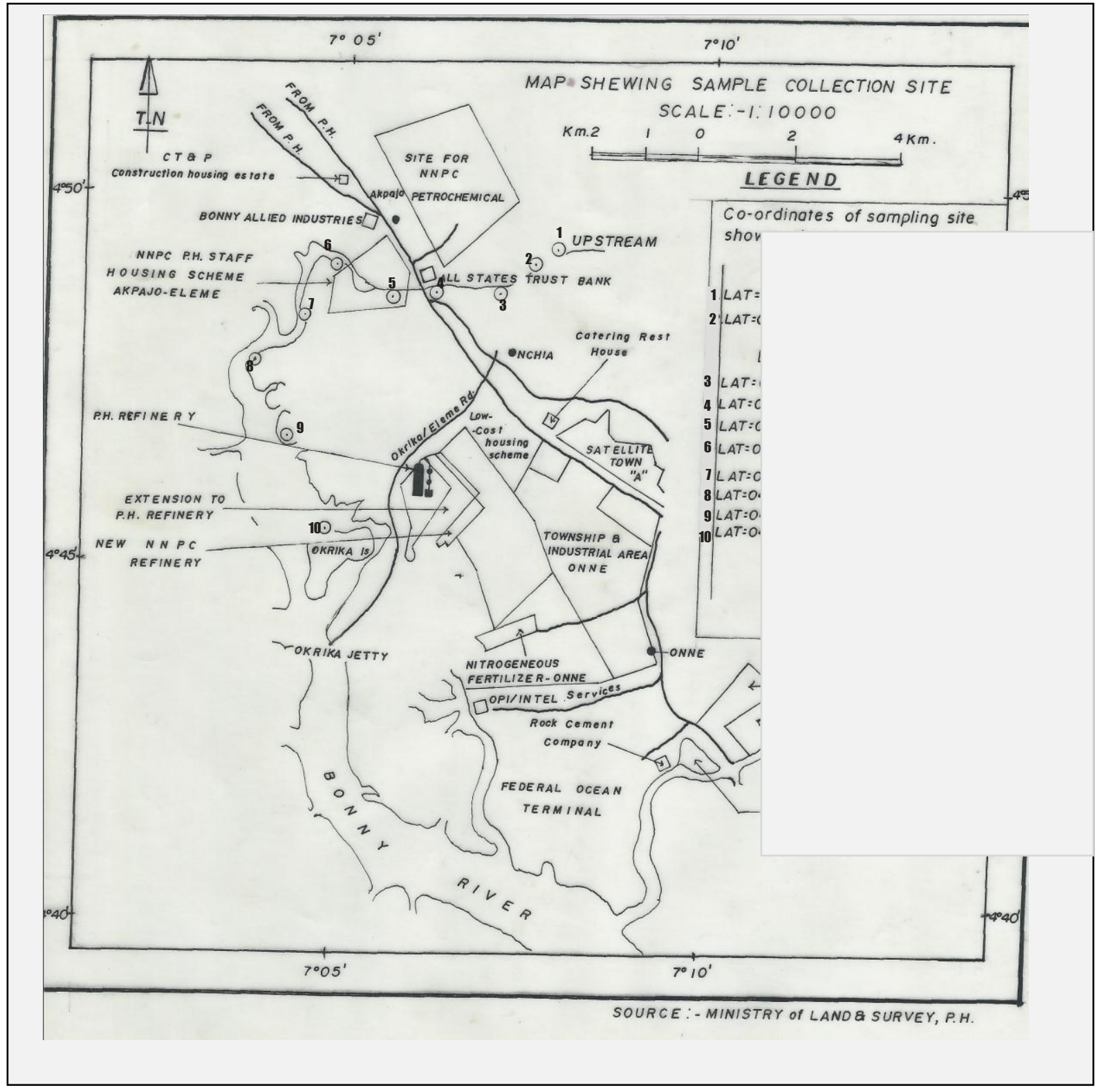

Fig. 1: Map of the creek showing Sample collection sites. 


\subsection{Sampling procedure}

The sampling locations were chosen on the basis of their accessibility and representation of the environment and the entire aquatic area. Sampling, being an essential part of any analysis, involves collection of a representative portion of the materials being investigated. According to Udosen (1991), the choice of good sampling technique is a prerequisite for accurate data collection. Sampling of surface water was carried out monthly (July 2010-February 2011) for the determination of some water quality parameters viz dissolved oxygen, biological oxygen demand, chemical oxygen demand, sodium, potassium, calcium, magnesium, sulphate, phosphate and oil and grease.

\section{Determination of Dissolved Oxygen (DO)}

The concentration of dissolved oxygen in water was determined insitu using multi parameter sensor 156.

\section{Calcium and magnesium}

These ions are responsible for the hardness of water and the exchangeable ions concentration was determined using the modified Unicam Atomic Absorption Spectrophotometer (APHA, 1998).

\section{Sodium and potassium}

The standard method(SM) used for the determination of the concentration of sodium and potassium ions in water was the flame emission method (APHA, 1998).

\section{Determination of Biological oxygen demand $\left(\mathrm{BOD}_{5}\right)$}

After the dissolved oxygen had been fixed and the manganese (II) and (III) hydroxide precipitated, the sample was acidified to a $\mathrm{pH}$ of between 1.0-2.5, (a medium that enhances the oxidizing property of manganese (II) ion- $\mathrm{Mn}^{2+}$.

To the precipitate of Winkler's solution I and II, was added $50 \% \mathrm{H}_{2} \mathrm{SO}_{4}(4 \mathrm{ml})$ and starch indicator $(2$ drops), giving a bluish coloured solution. This solution $(100 \mathrm{ml})$ was then titrated with $0.0125 \mathrm{M}$ thiosulphate $\left(\mathrm{Na}_{2} \mathrm{~S}_{2} \mathrm{O}_{3} \cdot 5 \mathrm{H}_{2} \mathrm{O}\right)$ solution to a light yellow coloured solution and the titration was continued until the solution became colourless, signifying end-point (APHA, 1998).

Two DO determinations were carried out ie, one before incubation and the other, after five days incubation respectively. The BOD was subsequently calculated from the difference between the two DO levels (APHA, 1998).

\section{Sulphate ion $\left(\mathrm{SO}_{4}{ }^{2-}\right)$}

$10 \mathrm{ml}$ of water sample was pipetted into $25 \mathrm{ml}$ volumetric flask and distilled water was added to bring the volume to approximately $20 \mathrm{ml}$. Gelatinous $-\mathrm{BaCI}_{2}$ reagent $(1 \mathrm{ml})$ was added and made up to the mark with distilled water to form a bariumsulphate turbidity. The content was thoroughly mixed and allowed to stand for 30 minutes. The optical density (OD) corresponding to the absorbance of the barium sulphate turbidity was measured spectrophotometrically using a $\mathrm{HACH}$ DR/2010 portable Datalogging Spectrophotometer at a wavelength of $420 \mathrm{~nm}$. Readings were taken at intervals of 30 seconds over a period of 4 minutes and the maximum reading recorded. A calibration curve was prepared using analytical grade anhydrous potassium sulphate $\left(\mathrm{K}_{2} \mathrm{SO}_{4}\right)$ that covered the $0.01-1.6 \mathrm{mg} / \mathrm{SO}_{4}{ }^{2-}$ range. From the calibration plot, the concentrations of sulphate ion equivalent to the observed optical densities (absorbance of the test and blank solution) were read off and the level of sulphate ion in the sample obtained (APHA, 1998).

\section{Chemical Oxygen Demand (COD)}

The chemical oxygen demand procedure adopted for the water samples according to the method by APHA (1998) based on the chromic acid oxidation of organic matter in the sample is as follows: into the chemical oxygen demand tubes was added $50 \mathrm{ml}$ of water sample. To the sample was added $0.5 \mathrm{~g}$ of mercury (II) sulphate. $10 \mathrm{ml}$ potassium dichromate solution was added to the sample (potassium dichromate solution was prepared by dissolving $12.259 \mathrm{~g}$ in 1 litre of deionised water). Also added was $15 \mathrm{ml}$ sulphuric acid solution. The sample tube was fitted with a condenser and refluxed for about two hours. The sample was cooled to room temperature and diluted with deionised water to $100 \mathrm{ml}$. To the resultant solution was added three drops of ferroin indicator. The solution was titrated with $0.23 \mathrm{M}$ ferrous ammonium sulphate solution (FAS) to pinkish end-point. The procedure was repeated with deionised water as blank.

\section{$\mathrm{ml}$ of sample}

COD $(\mathrm{mg} / \mathrm{l})$ was calculated as follows:

$$
\operatorname{COD}(\mathrm{mg} / \mathrm{l})=\underline{(\mathrm{A}-\mathrm{B}) \mathrm{M}_{\mathrm{FAS}}} \times 8000
$$

where; 
A = volume of FAS used for blank without sample

B $\quad=$ volume of FAS used for sample.

MFAS $=$ Molarity of FAS used.

Phosphate ion determination (stannous chloride method)

To $25 \mathrm{ml}$ of the water sample was added $0.5 \mathrm{ml}$ of ammonium molybdate $\left(\mathrm{NH}_{4}\right)_{6} \mathrm{Mo}_{7} \mathrm{O}_{24} \cdot 4 \mathrm{H}_{2} \mathrm{O}$ $40.1 \mathrm{~g} / 500 \mathrm{ml}$ solution, distilled $\mathrm{H}_{2} \mathrm{O}$, and 2 drops of stannous chloride $\left(\mathrm{SnCI}_{2} \cdot 2 \mathrm{H}_{2} \mathrm{O}-2.5 \mathrm{~g} / 100 \mathrm{ml}\right.$ glycerol $)$ solution. The solution was mixed by swirling. A blue colour developed within an hour. The intensity of the colour was measured using a spectrometer (spectronic 21D) at 690nm (APHA, 1998). The concentration of phosphate was determined as follows:

Phosphate, $\mathrm{mg} / \mathrm{l}=(\mathrm{A}-\mathrm{B}) \mathrm{C}$

Where, $A=$ absorbance of sample

$\mathrm{B}=$ absorbance of blank sample

$\mathrm{C}=$ volume of standard phosphate

\section{Results and Discussion}

The results of the investigation of the levels of some physicochemical Parameters from Eleme creeks are presented in Table 1 as shown below. Results from Table 1 show that the levels of the parameters vary from one location to another. It is discovered that at locations 1 and 2, low levels of parameters were recorded probably because these locations are off stream to the point source- petrochemical (location 3 ). In almost all the parameters, highest levels were obtained at the point source which is an indication that the petrochemical company may have been responsible for this experience. As one move towards the downstream locations, it is noticed that there is a gradual decrease in the levels of these parameters probably due to dilution. Table 2 below revealed that the mean levels of the parameters were generally high in the dry season as compared to the wet season. The high levels recorded in the dry season could be ascribed to the low volume of water and favourable weather condition resulting to high productivity and high waste generation.

Table 1: The Mean and Standard Deviation of some Physicochemical Parameters from different locations.

\begin{tabular}{|c|c|c|c|c|c|c|c|c|c|c|c|}
\hline \multicolumn{12}{|c|}{ Locations } \\
\hline Parameters & 1 & 2 & 3 & 4 & 5 & 6 & 7 & 8 & 9 & 10 & $\mathrm{X} \pm \mathrm{SD}$ \\
\hline DO (mg/l) & 4.13 & 3.78 & 2.61 & 2.85 & 3.12 & 3.28 & 3.04 & 3.04 & 3.45 & 3.52 & $\begin{array}{l}3.286 \pm \\
0.603\end{array}$ \\
\hline COD (mg/l) & 38.25 & 49.37 & 75.25 & 75.37 & 66.62 & 64.12 & 64.12 & 64.50 & 64.00 & 53.62 & $61.32 \pm 12.65$ \\
\hline $\mathrm{BOD}_{5}(\mathrm{mg} / \mathrm{l})$ & 24.73 & 29.65 & 52.35 & 53.75 & 44.63 & 44.23 & 43.83 & 44.76 & 47.71 & 45.47 & $43.11 \pm 9.618$ \\
\hline $\mathrm{PO}^{3-}(\mathrm{mg} / \mathrm{l})$ & 0.04 & 0.05 & 0.04 & 0.05 & 0.04 & 0.03 & 0.03 & 0.04 & 0.04 & 0.03 & $\begin{array}{l}0.042 \pm \\
0.009\end{array}$ \\
\hline $\mathrm{SO}_{4}^{2-}(\mathrm{mg} / \mathrm{l})$ & 14.00 & 14.21 & 20.15 & 21.30 & 19.80 & 19.08 & 18.56 & 15.35 & 15.21 & 16.57 & $17.42 \pm 3.281$ \\
\hline $\mathrm{Mg}(\mathrm{mg} / \mathrm{l})$ & 1.63 & 1.64 & 1.59 & 1.55 & 1.95 & 1.37 & 1.08 & 1.46 & 1.31 & 1.33 & $\begin{array}{l}1.494 \pm \\
0.522\end{array}$ \\
\hline $\mathrm{K}(\mathrm{mg} / \mathrm{l})$ & 3.08 & 1.77 & 4.64 & 4.50 & 3.18 & 2.73 & 2.93 & 2.88 & 2.75 & 2.48 & $\begin{array}{l}3.097 \pm \\
3.097\end{array}$ \\
\hline $\mathrm{Ca}(\mathrm{mg} / \mathrm{l})$ & 2.89 & 2.13 & 3.76 & 2.64 & 3.10 & 2.57 & 1.98 & 2.32 & 2.41 & 2.08 & $\begin{array}{l}2.592 \pm \\
0.769\end{array}$ \\
\hline $\mathrm{Na}(\mathrm{mg} / \mathrm{l})$ & 3.58 & 3.18 & 4.20 & 3.84 & 3.37 & 3.21 & 3.13 & 2.53 & 2.57 & 2.39 & $\begin{array}{l}3.205 \pm \\
0.876\end{array}$ \\
\hline $\begin{array}{l}\text { Oil and } \\
\text { grease }(\mathrm{mg} / \mathrm{l})\end{array}$ & 3.27 & 3.69 & 7.33 & 7.70 & 6.59 & 7.20 & 6.68 & 6.52 & 6.15 & 5.63 & $\begin{array}{l}6.080 \pm \\
1.566\end{array}$ \\
\hline
\end{tabular}

Table 2: The Mean levels of some Physiochemical Parameters during wet and dry season

\begin{tabular}{|l|l|l|l|l|}
\hline & \multicolumn{1}{|c|}{ Wet Season } & \multicolumn{2}{c|}{ Dry Season } \\
\hline Parameters & Mean & Range & Mean & Range \\
\hline DO $(\mathrm{mg} / \mathrm{l})$ & 3.470 & $2.825-4.745$ & 3.090 & $2.4125-3.547$ \\
\hline $\mathrm{COD}(\mathrm{mg} / \mathrm{l})$ & 58.200 & $33.75-69.75$ & 66.020 & $42.75-80.75$ \\
\hline $\mathrm{BOD}_{5}(\mathrm{mg} / \mathrm{l})$ & 40.590 & $22.22-51.35$ & 45.630 & $27.25-56.15$ \\
\hline $\mathrm{PO}^{3-}(\mathrm{mg} / \mathrm{l})$ & 0.043 & $0.0325-0.557$ & 0.043 & $0.033-0.0507$ \\
\hline $\mathrm{SO} 4-(\mathrm{mg} / \mathrm{l})$ & 16.450 & $13.00-19.28$ & 18.400 & $15.01-23.58$ \\
\hline $\mathrm{Mg}(\mathrm{mg} / \mathrm{l})$ & 1.247 & $0.708-1.475$ & 1.789 & $1.463-2.256$ \\
\hline $\mathrm{K}(\mathrm{mg} / \mathrm{l})$ & 2.813 & $1.172-5.397$ & 3.382 & $2.383-5.608$ \\
\hline $\mathrm{Ca}(\mathrm{mg} / \mathrm{l})$ & 2.326 & $1.444-2.955$ & 2.857 & $2.306-4.012$ \\
\hline $\mathrm{Na}(\mathrm{mg} / \mathrm{l})$ & 3.189 & $2.356-4.764$ & 3.220 & $2.439-4.180$ \\
\hline Oil and grease $(\mathrm{mg} / \mathrm{l})$ & 5.740 & $2.937-7.427$ & 6.040 & $3.62-7.972$ \\
\hline
\end{tabular}




\section{Dissolved oxygen (DO)}

The mean concentration of dissolved oxygen in surface water from Eleme creeks with standard deviation was $3.28 \pm 0.603 \mathrm{mg} / \mathrm{l}$. The lowest level of $2.619 \mathrm{mg} / \mathrm{l}$ was recorded at location 3 (PTC) while the highest DO content of $4.134 \mathrm{mg} / 1$ was obtained at location 1 (AGA 1). The mean level of dissolved oxygen recorded during the wet season was $3.47 \mathrm{mg} / \mathrm{l}$ while $3.09 \mathrm{mg} / \mathrm{l}$ was the mean concentration obtained during the dry season. The 2-way ANOVA results show that there was a significant variation in the concentration of DO with sampling locations and sampling periods. The dissolved oxygen concentration was lower compared to recommended tolerable limit of 5.0mg/l for fish (ANZECC, 2000). The Eleme Petrochemicals Company EIA (1992) study obtained DO level of $6.38 \mathrm{mg} / \mathrm{l}$ in surface water. Lower levels of dissolved oxygen are often linked to fish kill incidents. Optimum levels of dissolved oxygen are necessary for growth, and hence high production yield. Dissolved Oxygen level lower than $5.0 \mathrm{mg} / \mathrm{l}$ can exert undue stress on fish, and levels less than $2 \mathrm{mg} / \mathrm{l} \mathrm{may}$ result in death.

\section{CHEMICAL OXYGEN DEMAND (COD)}

The mean COD in water from Eleme creeks with standard deviation was $61.32 \pm 12.65 \mathrm{mg} / \mathrm{l}$. The lowest concentration of $38.25 \mathrm{mg} / \mathrm{l}$ was found at location I (AGA) while the highest concentration of $75.37 \mathrm{mg} / \mathrm{l}$ was found at location 4 (DRG). The mean concentration recorded in wet season was $58.2 \mathrm{mg} / \mathrm{l}$ while that in the dry season was $66.02 \mathrm{mg} / \mathrm{l}$. Results of the 2-way ANOVA show that there was a significant variation in the mean COD level with sampling locations and sampling periods. The recommended level of COD discharged from petrochemicals manufacturing is 150mg/l (World Bank, 1990).

\section{Biological Oxygen Demand $\left(\mathrm{BOD}_{5}\right)$}

The mean level of BOD for surface water from Eleme creeks with standard was $43.11 \pm 9.61 \mathrm{mg} / \mathrm{l}$. The lowest concentration of $24.73 \mathrm{mg} / \mathrm{l}$ was obtained at location 1 (AGA1) while the highest concentration of $53.75 \mathrm{mg} / \mathrm{l}$ was obtained at location 4 (DRG). The mean level recorded in the wet season was $40.59 \mathrm{mg} / \mathrm{l}$ and $45.63 \mathrm{mg} / \mathrm{l}$ in the dry season. Results of the 2-way ANOVA show that there was a significant variation in the mean BOD with sampling locations and sampling periods. The results of the study were generally high compared to that of FEPA (1991) with a level of $0.27 \mathrm{mg} / \mathrm{l}$. Such high levels at all locations may accelerate the growth of bacteria in creeks and rivers, whose activities are capable of depleting DO. This may have been responsible for low levels of DO in this study.

\section{Phosphate $\left(\mathrm{PO}_{4}{ }^{3-}\right)$}

The mean concentration of phosphate present in surface water from Eleme creeks with standard deviation was $0.042 \pm 0.09 \mathrm{mg} / \mathrm{l}$. The lowest level of $0.033 \mathrm{mg} / \mathrm{l}$ was obtained at location $10(\mathrm{OKR})$ while the highest level of $0.05 \mathrm{mg} / 1$ was obtained from location 4 (DRG). The mean phosphate level recorded in the wet season was $0.042 \mathrm{mg} / \mathrm{l}$ while the mean concentration of phosphate in the dry season was $0.042 \mathrm{mg} / \mathrm{l}$. Results of the 2-way ANOVA show that there was a significant variation in the mean level of phosphate with sampling locations and sampling periods. The levels of phosphate obtained in this study are similar to the levels obtained in some inland water bodies (Egborge and Fagade, 1979; Garg et al., 2010). Higher concentrations of phosphate are rarely obtained since as soon as it enters a water system, it is rapidly taken up by plants.

\section{Sulphate $\left(\mathrm{SO}_{4}{ }^{2-}\right)$}

The mean concentration of sulphate in surface water from Eleme creeks with standard deviation was $17.43 \pm 3.28 \mathrm{mg} / \mathrm{l}$. The lowest level of $14.0 \mathrm{mg} / \mathrm{l}$ was obtained at location 1 (AGA I) while the highest level of $20.15 \mathrm{mg} / \mathrm{l}$ was obtained at location 3 (PTC). The mean level recorded in the wet season was $16.45 \mathrm{mg} / \mathrm{l}$ while that in the dry season was $18.4 \mathrm{mg} / \mathrm{l}$. Results of the 2-way ANOVA show that there was a significant variation in the concentration of sulphate with sampling locations and sampling periods. Sulphate levels in this study are in agreement with those from studies on Kaduna River in Nigeria (Mahre et al., 2007). Surface water criterion for sulphate is 200mg/l (FEPA, 1991). However, the Eleme Petrochemicals Company EIA (1992) study obtained levels of sulphate of $2.50 \mathrm{mg} / \mathrm{l}$ in surface water from Eleme creeks.

\section{Magnesium ion $\left(\mathrm{Mg}^{2+}\right)$}

The mean concentration of magnesium in surface water from Eleme creeks with standard deviation was $1.494 \pm 0.522 \mathrm{mg} / \mathrm{l}$. The lowest concentration of $1.086 \mathrm{mg} / \mathrm{l}$ was obtained at location 7 (QTR) while the highest concentration of $1.954 \mathrm{mg} / \mathrm{l}$ was obtained at location 4 (DRG). The mean concentration obtained in the wet season was $1.24 \mathrm{mg} / \mathrm{l}$ and $1.78 \mathrm{mg} / \mathrm{l}$ was obtained during the dry season. Results of the 2-way ANOVA show that there was a significant variation in the concentration of magnesium with sampling locations and sampling points. The concentration of magnesium obtained during the Eleme Petrochemicals Company EIA study for water was $0.17 \mathrm{~m} / \mathrm{l}$. The levels of magnesium however in the study are in good agreement with recent 
observations made about Ramsayer reservoir, India (Garg et al., 2010) but are not consistent with those of Kallar, Kallar Lakes with a range of $15.48-248.12 \mathrm{mg} / \mathrm{l}$ in Pakistan (Furhan et al., 2006). The levels of magnesium from the study are far lower than $30 \mathrm{mg} / \mathrm{l}$ recommended for lake water.

\section{Potassium ion $\left(\mathrm{K}^{+}\right)$}

The mean concentration of potassium with standard deviation in surface water from Eleme creeks was $3.09 \pm 3.097$. The lowest concentration of $1.778 \mathrm{mg} / 1$ was obtained at location 2 (AGA2) while the highest concentration of $4.64 \mathrm{mg} / \mathrm{l}$ was recorded at location 3 (PTC). The mean concentration obtained during the wet season was $2.813 \mathrm{mg} / \mathrm{l}$ while the mean concentration obtained during the dry season was $3.38 \mathrm{mg} / \mathrm{l}$. Results of the 2-way ANOVA show that there was a significant variation in the concentration of potassium with sampling locations and sampling points. The concentrations obtained from this study are considerably in agreement with the $3.26 \mathrm{mg} / \mathrm{l}$ obtained for water from Eleme (Eleme Petrochemicals EIA Company, 1992) and below the maximum permissible limit of $12 \mathrm{mg} / \mathrm{l}$ by European Economic Community. Potassium ion, like other metal ions such as $\mathrm{Ca}^{2+}, \mathrm{Na}^{+}$and $\mathrm{Mg}^{2+}$ are indicators of organic pollution.

\section{Calcium ion $\left(\mathrm{Ca}^{2+}\right)$}

The mean concentration of calcium in surface water from Eleme creeks with standard deviation was $2.59 \pm 0.76 \mathrm{mg} / \mathrm{l}$. The lowest concentration of $1.98 \mathrm{mg} / \mathrm{l}$ was obtained at location7 (ABM) while the highest concentration of $3.76 \mathrm{mg} / \mathrm{l}$ was obtained at location 3 (PTC). The mean concentration obtained during the wet season was $2.32 \mathrm{mg} / \mathrm{l}$ while the mean concentration obtained during the dry season was $2.85 \mathrm{mg} / \mathrm{l}$. Results of the 2-way ANOVA show that there was a significant variation in the concentration of calcium with sampling locations and sampling periods. The concentration of calcium obtained for the analysis of water from Eleme was $0.29 \mathrm{mg} / \mathrm{l}$ during Eleme Petrochemical Company EIA, (1992) study. The mean level of calcium in the present study is in agreement with the findings for Ramsayer reservoir in India (Garg et al., 2010).

\section{Sodium ion $\left(\mathrm{Na}^{+}\right)$}

The mean concentration of sodium in surface water from Eleme creeks with standard deviation was $3.205 \pm 0.876 \mathrm{mg} / \mathrm{l}$. The lowest concentration of $2.39 \mathrm{mg} / \mathrm{l}$ was obtained at location 10 (OKR) while the highest concentration of $4.20 \mathrm{mg} / \mathrm{l}$ was obtained at location 3 (PTC). The mean concentration obtained during the wet season was $3.189 \mathrm{mg} / 1$ while $3.22 \mathrm{mg} / \mathrm{l}$ was the concentration obtained during the dry season. Results of the 2way ANOVA show that there was a significant variation in the concentration of sodium with sampling locations but no significant variation with the sampling periods.

Eleme Petrochemicals Company EIA (1992) result for sodium from Eleme creeks was $0.29 \mathrm{mg} / \mathrm{l}$. Thus, the level of $\mathrm{Na}$ ion from the study is moderate. Sodium ion contributes to chlorides in water and a high content is an indication of organic pollution (Ventatasubramani and Meenambai, 2007).

\section{Oil and grease}

The mean concentration of oil and grease in surface water from Eleme creeks with standard deviation was $6.08+1.56 \mathrm{mg} / \mathrm{l}$. The lowest concentration of $3.27 \mathrm{mg} / \mathrm{l}$ was obtained at location 1 (AGA I) while the highest concentration of $7.70 \mathrm{mg} / \mathrm{l}$ was obtained at location 4 (DRG). The mean concentration obtained during the wet season was $5.74 \mathrm{mg} / \mathrm{l}$ and $6.04 \mathrm{mg} / \mathrm{l}$ was obtained during the dry season. The results of 2-way ANOVA show that there was a significant variation in the concentration of oil and grease with sampling locations and the sampling periods. The levels of oil and grease recorded in this work are clearly below the recommended level of $10 \mathrm{mg} / \mathrm{l}$ (FEPA, 1991; World Bank, 1990).

\section{Conclusion}

The study conducted to investigate the impact of Eleme Petrochemicals Company on the levels of some physicochemical parameters revealed that except for DO, BOD and COD that were out of the national and international recommended limits, all others were within the specified limits. These parameters (DO, COD and BOD) are important water quality parameters and been out of limits are indications that the creek is polluted and are very detrimental to aquatic lives. These results were out of range when compared with the impact assessment study carried by the Eleme Petrochemical Company in 1992 indicating that the operations and construction within the company may have been responsible for it. 


\section{References}

[1]. ANZECC (2000). Australian and New Zealand guidelines for fresh and marine water quality. Austrilian and New Zealand environment and conservation council.

[2]. APHA (1992). Standard methods for the Examination of water and waste, $18^{\text {th }}$ Edition. American Public Health Association, American Water Works Association and Water Environmental Fedration (APHA-AWWA-WEF), Published by the American Public Health Association, Washington D.C.

[3]. APHA (1998). Standard Method for examination of water and wastewater. 20 ${ }^{\text {th }}$ Edition. American Public Health Association, American Water Works Association and Water Environmental Fedration (APHA-AWWA-WEF), Published by the American Public Health Association, Washington D.C.

[4]. Akumagba, P.E. (2001). Plastic in solid waste management: Implication for solid waste disposal in Nigeria. Delta Chemist, Magazine of the Delta State Chapter of the Chemical Society of Nigeria.

[5]. Egborge, A.B.M \&Fagade, S.O. (1979). Notes on the hydrobiology of the Wikki Warm springs, Yankari Games Reserve. Nigeria Aquaculture and Hydrobiology 26(2):17-23.

[6]. Eleme Petrochemicals Company Environmental Impact Assesment study (1992).

[7]. FEPA (1991).Federal Environmental Protection Agency: National Interim Guidelines and Standards for industrial effluents, gaseous emissions and hazardous waste management in Nigeria. Garki, F.C.T; Abuja Nigeria.

[8]. Fokmare, A. K. \&Musaddiq, M. (2002). A study of physicochemical characteristics of kapsi lake and puma river waters in Akola district of Maharastra (India). National Environmental Pollution Technology 1:261-263.

[9]. Furhan, I., Nadeem, R., Muhammed, A. \&Muhammed, A. (2006). Contamination of KallarKahar Lake by inorganics and heavy metals in their temporal variation. Journal of Applied Science and Environmental Management 10(2):95-98.

[10]. Garg, R.K., Rao, R.J., Uchchariya, D., Shuka, G. \&Satsena, D. N. (2010). Seasonal variations in water quality and major threats to Ramsagar reservoir, India. African Journal of Environmental Science and Technology (AJEST) 4(2):061-076.

[11]. Ifeadi, C, N. \&Nwankwo, J.N. (1983). Oil spill incidence in Nigeria Petroleum Industry. A critical analysis NAPECTOR 8(4) 511.

[12]. Mahre, M.Y., Akan, J.C., Moses, E.A. \&Ogugbuaja, V.O.(2007). Pollution indicators in River Kaduna, Kaduna State, Nigeria. Trends in Applied Science Research 2(4):304-311.

[13]. Nwineewii, J.D. (2000). The distribution of total hydrocarbon (THC) in tissues of shrimp (PaneausMonodon) from Onne River, Rivers State, Nigeria. M.Sc Thesis in the University of Port Harcourt, Port Harcourt.

[14]. Ogodo, A.D. (2008). Effective waste management issues in Nigeria. An article published in "Chemistry in Nigeria", A National Magazine of Chemical Society of Nigeria 3(2), 16-19.

[15]. Ogodo, A.D. (2001). The environmental impact of waste on host (Ekpan-Uvwie) community. Paper presented at the 24 ${ }^{\text {th }}$ Annual International Conference of the Chemical Society of Nigeria held at NICON Hilton Hotel, Abuja $24^{\text {th }}-28^{\text {th }}$ September.

[16]. Udosen, E.D.(1991). Aqua-terrestrial environmental pollution studies of inorganic substances from two industrial firms in Akwalbom State. Ph.D Thesis, University of Calabar, Calabar.

[17]. Ventatasubramani, R. \&Meenambai, T. (2007). Study of sub-surface water quality of Mattupalayan. Taluk of Coimbatore district Tami/Nadu. National Environmental Pollution Technology 6:307-310.

[18]. World Bank (1990). The petrochemicals industry in developing Asia: A review of the current situation and prospects for development in the 1990s by walterVergara and Dominique Babelon. World Bank Technical Paper Number 113, Industry and Energy Series, Washington, D.C. 